\title{
FAST-SLOW CONTINUUM IN THE LIFE HISTORY PARAMETERS OF LADYBIRDS REVISITED
}

\author{
A. F. G. DIXON ${ }^{1,2 *}$, B. AGARWALA ${ }^{3}$, J.-L. HEMPTINNE ${ }^{4}$, \\ A. HONĚK ${ }^{5}$ AND V. JAROŠÍK ${ }^{6,7}$
}

\author{
${ }^{1}$ Department of Biodiversity Research, Global Change Research Centre AS CR, Na Sádkách 7, České Budějovice, Czech Republic \\ ${ }^{2}$ School of Biological Sciences, University of East Anglia, Norwich, NR4 7TJ, U.K. \\ ${ }^{3}$ Department of Life Science, Tripura University, Agartala, Tripura, P.O. Agartala College, PIN -79904, India \\ ${ }^{4}$ Université de Toulouse - Ecole nationale de Formation agronomique ; UMR CNRS 5174 "Evolution et Diversité biologique", BP 22687, \\ F-31326 Castanet-Tolosan Cedex, France \\ ${ }^{5}$ Research Institute of Crop Production, Drnovská 507, CZ 16106 Prague 6 - Ruzynĕ, Czech Republic \\ ${ }^{6}$ Department of Ecology, Faculty of Science, Charles University Prague, Viničná 7, CZ-128 01 Prague, Czech Republic \\ ${ }^{7}$ Department of Invasion Ecology, Institute of Botany Academy of Sciences of the Czech Republic, CZ-252 43 Průhonice, Czech Republic \\ ${ }^{\star}$ Corresponding author: a.f.dixon@uea.ac.uk
}

\section{ABSTRACT}

A previous study of the rate of development of larvae of aphidophagous and coccidophagous ladybirds indicated that they both had the same lower developmental threshold (Ldt) but that the coccidophagous species developed more slowly than the aphidophagous species. The current analysis of the rates of development of the eggs of 48 species belonging to 8 tribes, which were kept at a range of different temperatures, indicates that ladybirds do not all have the same Ldt, but that the of eggs of aphidophagous Coccinellini develop faster than those of coccidophagous Chilocorini and more importantly those of the aphidophagous genus Scymnus and the coccidophagous Nephus, both belonging to the same robust tribe, the Scymnini, also differ, with those of the latter genus developing more slowly. Possible reasons for this are discussed.

Keywords: aphidophagous, Coccinellidae, coccidophagous, development of eggs, fast and slow development, life history parameters

\section{Introduction}

The life history parameters of aphidophagous and coccidophagous ladybirds differ. The rate of larval development, relative growth rate, metabolic rate, speed of movement, reproductive investment, reproductive rate and rate of ageing of aphidophagous ladybirds are all faster than those of coccidophagous ladybirds, and this reflects the marked differences in the speed of life of their respective prey (Dixon 2000). As aphids are parthenogenetic and telescope their generations they have prodigious rates of increase compared with coccids. In addition, coccidophagous ladybirds are more successful biological control agents than aphidophagous species and this appears to be mainly a consequence of the former developing faster and the latter slower than their prey (Dixon 2000).

The rate of development of ladybirds is determined both by food quality and temperature. Each species tends to feed on relatively few species of prey in nature. For convenience, however, laboratory studies have depended on the mass production of a few species of aphids, which appear to be acceptable prey for the ladybirds studied. It is suggested, however, that prey animals differ in their content of limiting nutrients, like methionine, and Liebig's law applies (Cohen and Brummett 1997), or of toxic secondary plant substances they sequester from their host plants (Dixon 1998). Although a particular species of aphid is clearly not similarly suitable for all species of aphidophagous ladybirds it is more likely that the eggs of each species of ladybird are well provided with the nutrients necessary for embryonic development. In addition, as is recorded for many groups of organisms, large species of ladybirds lay larger eggs than small species but they are not proportionally larger (Stewart et al. 1991). If one assumes that the size of the cells of small and large species of ladybird are the same, then as the larvae that hatch from eggs laid by large species are larger than those that hatch from eggs laid by small species and both develop from a single cell, the expectation is that eggs laid by large species will take longer to hatch than those laid by small species. Metabolic theory also predicts that the development rate of eggs is proportional to $\mathrm{Wt}^{0.25}$ (Brown et al. 2004).

Thus, it was decided to use the data available in the literature on the rate of development of eggs of ladybirds at different temperatures to determine whether the lower temperature threshold for the development of eggs is the same for all ladybirds (Dixon et al. 1997; Jarosik et al. 2002) and whether those of coccidophagous species develop more slowly than those of aphidophagous species (Dixon 2000).

\section{Material and Methods}

\section{The relationship between rate of development and egg mass}

In order to avoid the effect phylogeny might have on the rate of development, eggs of 12 species of ladybirds of the tribe Coccinellini were kept at $22{ }^{\circ} \mathrm{C}$ and their rate of development determined. Egg mass ranged from 0.1 (Adalia decempunctata) to $0.8 \mathrm{mg}$ (Anisolemnia dilatata). 


\section{Lower temperature threshold for development}

A survey of the literature provided 83 data sets of the time it takes the eggs of 48 species of ladybirds, belonging to 8 tribes, to hatch when kept at from 1 to 8 different temperatures falling within the range of the linear relationship between developmental rate and temperature. This data was first used to test the hypothesis that all ladybirds have the same lower developmental threshold $(L d t)$, $10{ }^{\circ} \mathrm{C}$ (Dixon et al. 1997).

\section{Rate of development of the eggs of aphidophagous and coccidophagous species of ladybird}

The above data was used also to determine whether the rates of development of the eggs of 23 species of Coccinellini, all of which feed on aphids, and 4 species of Chilocorini, all of which feed on coccids, differ. Then to factor out any effect that phylogeny might have, the rate of development of the eggs of 8 species of Scymnus and 3 of Nephus, which both belong to the tribe Scymnini, were compared.

\section{Statistical analysis of the data:}

a) The relationship between rate of development and egg mass: The exponential relationship between rate of development and egg mass was analyzed using a curve fitting routine and by regression after logarithmic transformation of the values on both axes.

b) Lower temperature threshold for development of the eggs of ladybirds in general and that of the eggs of aphidophagous and coccidophagous species of ladybird in particular: The hypothesis that all ladybirds have the same lower developmental threshold $10{ }^{\circ} \mathrm{C}$ was tested by expressing the rate of development $(R D)$ and temperature $(t)$ by a linear regression: $R D=a+b t$, where $a$ is the intercept with the $y$-axis, and $b$ the slope of the linear function. From this equation, the lower developmental threshold, i.e. the temperature when $R D=0$ and $t=L d t$, was estimated as $L d t=-a / b$ (e.g. Jarošík et al. 2002). The $95 \%$ confidence interval of the $L D T$ was used to determine whether the $L d t$ differs significantly from $10^{\circ} \mathrm{C}$. This was done by shifting the $y$-axis to the $L d t$ (at which point the developmental rate intercepts the temperature axis) by subtracting $L d t$ from temperature values and by calculating standard error of the shifted zero intercept (see e.g. Crawley 1993, p. 276-277).

To test the hypothesis that the rates of development of the eggs of aphidophagous and coccidophagous species differ, the data were evaluated by ANCOVA in which the rate of development was regressed on temperature with a different intercept and a different slope for aphidophagous and coccidophagous species. Parameters of this model were inspected for significance by deletion tests, following Crawley (1993). Deletion tests were repeated until a minimal adequate model (MAM) was established. In MAM, all non-significant parameters are removed, and all the remaining parameters are significantly $(\mathrm{P}<0.05)$ different from zero and from one another (Crawley 1993).

\section{Results}

\section{Rate of development and egg mass}

The rate of development declines exponentially with increase in egg mass, with the eggs of the largest species (Anisolemnia dilatata) taking 1.3 times longer to hatch at $22{ }^{\circ} \mathrm{C}$ than those of the smallest species (Adalia decempunctata). The best fitting curve is significant but only accounts for $34 \%$ of the variation. The correlation coefficient of the relationship between the logarithmically transformed rates of development and egg masses is $r=0.55$, which is significant $(P<0.05)$ if this is seen as a test of the prediction of a hypothesis and a one tailed test is used. That is, the hypothesis that the large eggs laid by the large species of ladybirds should take longer to hatch than the small eggs laid by the small species is well supported by these results but there is a lot of variability that remains to be accounted for, which may be partly resolved by more results, especially for large species.

\section{Lower temperature threshold for development}

The analysis of the relationship between rate of development and temperature for the eggs of 48 species belonging to 9 tribes of ladybirds revealed that ladybirds do not all have a lower developmental threshold of $10{ }^{\circ} \mathrm{C}$ (Fig. 1). The average value of the Ldt is 7.24 and the $95 \%$ confidence intervals $\left(7.21-7.26^{\circ} \mathrm{C}\right)$ do not overlap $10^{\circ} \mathrm{C}$. The previous analysis that indicated a common lower temperature threshold for development was based on the variation in rates of development of the larvae of aphidophagous and coccidophagous ladybirds that belonged mainly to two tribes, the Coccinellini and Chilocorini (Dixon et al. 1997). As the prediction of rate isomorphy is that all the developmental stages of a species will have the same lower developmental threshold (Jarošík et al. 2002) then the expectation was that if the different larval stages all have the same lower developmental threshold then so should the eggs. It is likely that the differences between species were obscured by the fact that as there was little data for each species the analysis was done on pooled data rather than by comparing data for different species. What is needed are extensive data sets recorded over a wide range of temperatures for many species. Comparison of this sort of data will undoubtedly reveal very big and highly significant differences between the lower developmental thresholds of the species. 


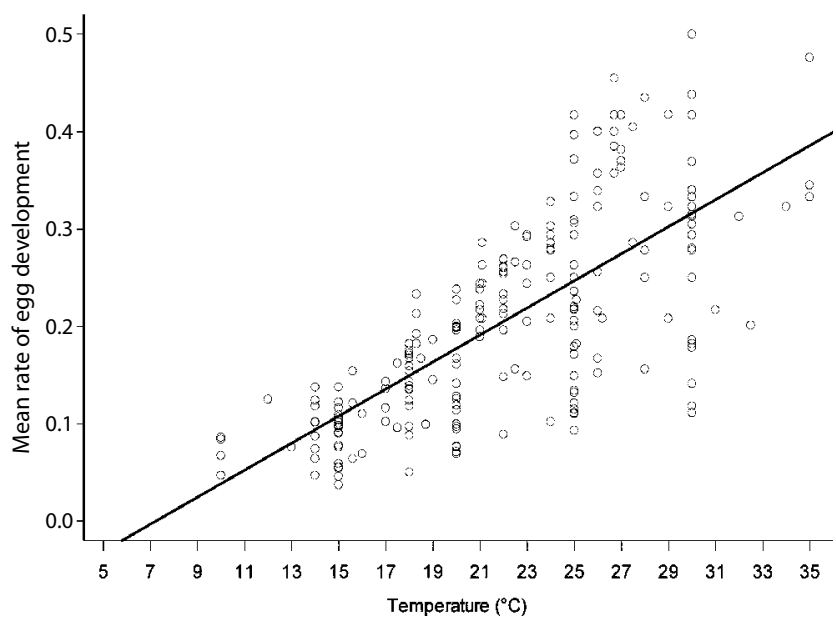

Fig. 1 The relationship between the average rates of development $(R D)$ at different temperatures $(t)$ of the eggs of 48 species of ladybirds belonging to 9 tribes. $R D=-0.10+0.014 t$. The overall significance of the model is $F=238.4$; d.f. $=1,277 ; P<0.001 ; R^{2}=0.51$ (Data from: Allawi 2006; Atlihan and Chi 2008; Babu and Azam 1987; Brown 1972; Butler 1982; Cheah and McClure 1998; Chong et al. 2005; Grafton-Cardwell et al. 2005; Hämäläinen and Markkula 1977; Hodek 1958; Honěk and Kocourek 1988; Huang et al. 2008; Katsarou et al. 2005; Kontodimas et al. 2004; Kreiter and Iperti 1984; Kutuk and Yigit 2007; LaMana and Miller 1995,1998; M'Hamed and Chemseddine 2001; McMullen 1967; Michels and Bateman 1986; Michels and Behle 1991; Miller 1992; Miller and Paustian 1992; Mota et al. 2008; Naranjo et al. 1990; Obrycki and Tauber 1981, 1982; Omkar and Pervez 2004; Orr and Obrycki 1990; Ponsonby and Copland 1996; Ren et al. 2002; Roy et al. 2002; Schanderl et al. 1985; Shüder et al. 2004; Srivastra and Omkar 2003; Stathas 2000; Stathas et al. 2002; Uygun and Atlihan 2000; Wright and Laing 1978; Zhao and Wang 1987.)

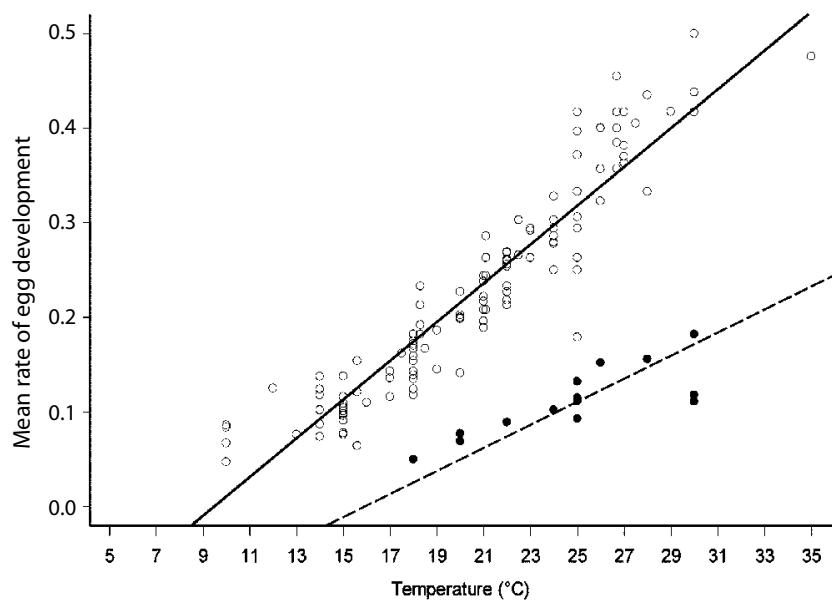

Fig. 2 The relationships between the average rates of development $(\mathrm{RD})$ at different temperatures $(\mathrm{t})$ of the eggs of aphidophagous Coccinellini (o) and coccidophagous ( $\bullet$ ) Chilocorini. Coccinellini: $R D=-0.19+0.020 t$; Chilocorini: $R D=-0.19+0.012 t$. The overall significance of the model is $F=536.5 ;$ d.f. $=2,140 ; P<0.001 ; R^{2}=0.88$.

Interestingly, the data for the eggs of Coccinellini (aphid eaters) are at the upper bound and those of the Chilocorini (coccid eaters) at the lower bound of the distribution depicted in Fig. 1. Analysis of the data for these two tribes indicates that the eggs of Coccinellini develop significantly faster than those of the Chilocorini $(\mathrm{F}=370.85$; d.f. $=1,140 ; \mathrm{P}<0.0001)$ and that their average lower developmental thresholds (Ldts) also differ significantly (Fig. 2) The Ldt of Chilocorini (mean and 95\% CI) is much higher, 15.92 (15.89-15.95), than that of Coccinellini, 9.47 (9.44-9.50). The clear difference in their rate of development cannot be attributed to egg size as the eggs of Chilocorini are not larger than those of Coccinellini.

\section{Rate of development of the eggs of aphidophagous and coccidophagous species of ladybird belonging to the same tribe}

The results of the above analyses of the whole data set, which includes information on species belonging to 9 tribes, or only two tribes, may be confounded by phylogenetic constraints (e.g. Harvey and Pagel 1991). In order to factor out the affects of phylogeny the data available for the aphid eating and coccid eating species of the tribe Scymnini were analyzed. Molecular data confirms that this is a robust tribe (Magro et al. 2010).

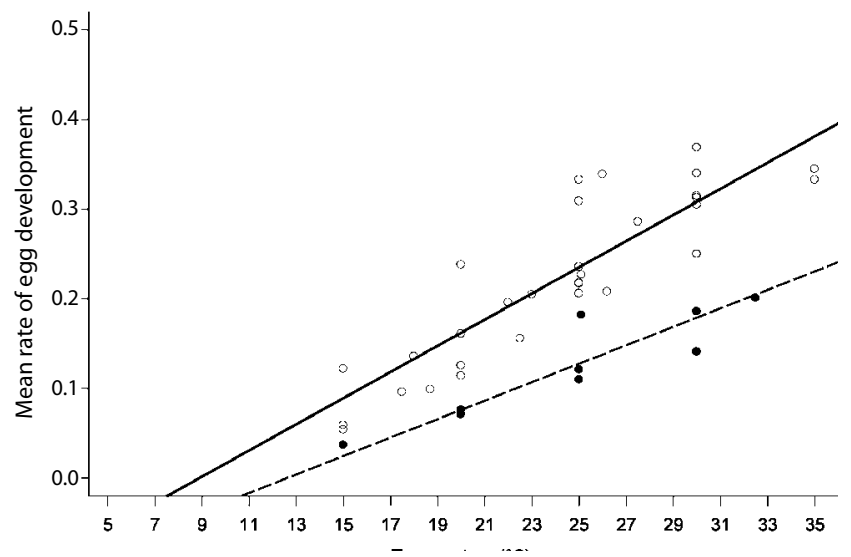

Fig. 3 The relationships between the average rates of development (RD) of eggs reared at different temperatures (t) of aphidophagous Scymnus (o) and coccidophagous Nephus ( $\cdot$ ), which both belong to the tribe Scymnini. Scymnus: $R D=-0.13+0.015 t$; Nephus: $R D=-0.13$ $+0.010 t$. The overall significance of the model is $F=99.14$; d.f. $=2$, $38 ; \mathrm{P}<0.001 ; \mathrm{R}^{2}=0.84$.

This analysis indicates that the rate of development of the eggs of the coccid eating species of the genus Nephus is significantly slower than that of the aphid eating species of Scymnus (F = 52.20; d.f. $=1,38 ; \mathrm{P}<0.001)$ and that their average lower developmental thresholds also differ (Fig. 3) $(\mathrm{F}=99.14$; d.f. $=2$, 38; $\mathrm{P}<0.0001$; Ldt Scymnus $=$ $=8.90$ [8.84-8.95]; Ldt Nephus $=12.61$ [12.55-12.66]).

\section{Discussion}

This analysis of the time taken for the eggs of ladybirds to hatch when kept at different temperatures confirms the results of a previous similar analysis of the time taken by ladybirds to complete their larval development (Dixon et 
al. 1997).The average rate of development of coccid eating species of ladybird is significantly slower than that of aphid feeding ladybirds. This study further indicates that this is unlikely to be due to a phylogenetic constraint as there are similar differences in the average rates of development of aphid eating and coccid eating species of ladybirds that belong to the same monophyletic tribe.

Interestingly, this marked difference in the rate of development is not mainly associated with size as is the case for Mammals (Bonner 1966; Sibly and Brown 2007). Metabolic theory predicts that small species will develop faster than large species but in the case of ladybirds coccidophagous species generally are smaller than aphidophagous species. The implication is that it must be advantageous for coccidophagous species to develop slower than would be predicted if their rate of development is mainly determined by metabolic constraints.

One possible explanation is that the food quality of the prey of the ladybirds that feed on coccids and aphids differs in terms of the limiting nutrients (Cohen and Brummett 1997) or toxic chemicals they contain (Dixon 1998). This is unlikely as the expectation is that the eggs are likely to be amply supplied with the nutrients required for embryonic development and, furthermore, it is possible to select ladybirds for improved performance on what are regarded as poor quality prey (Rana et al. 2002). However, this hypothesis needs to be rigorously tested.

Another possible explanation is that the lower developmental thresholds of aphid and coccid eating ladybirds differ. As the coccid eating ladybirds occur predominantly in subtropical and tropical regions and aphid eating ladybirds in temperate regions the prediction is that their Ldts will differ (Honěk 1996), which is supported by the results of this study. However, a preliminary analysis of the data for individual species indicates there is considerable overlap in the range of the Ldts of aphid and coccid eating ladybirds, but what is more significant is that relationships between the sum of the effective temperatures (SET) required for development and Ldt for coccid and aphid feeding ladybirds differ, with coccid eating species having considerably greater SET requirements than the aphid eating species. The SET requirement of a species is in part determined by food quality, which like temperature also affects the rate of development (Dixon 1998). Thus as concluded above it is important to determine to what extent, if any, food quality affects SET.

If the difference in the rates of development of coccidophagous and aphidophagous ladybirds is not attributable to differences in the food quality of their prey, which appears likely, then this poses a paradox that needs to be addressed. The intrinsic rate of increase $\left(\mathrm{r}_{\mathrm{m}}\right)$ and developmental rate $(1 / D)$ are correlated and $r_{m}$ is frequently used as a measure of fitness. Accepting this then the relatively slow rate of development of coccidophagous ladybirds is puzzling. Studies on Drosophila and fish indicate that the rate of development in these organisms is genetically controlled (Cruz do Nascimento et al. 2002; Devlin et al.
1994, 2001) and therefore subject to selection. The implication of this is that the reason why coccidophagous ladybirds don't develop faster is that they have been selected to develop slowly. It is likely the explanation is that it is advantageous for coccidophagous ladybirds to forage more slowly and consequently develop more slowly than aphidophagous ladybirds, but this needs further study.

\section{Acknowledgements}

A. F. G. D and A. H. were funded in part by project 522/08/1300 of Grant Agency of the Czech Republic. V. J. was supported by grants no. 206/09/0563 (Czech Science Foundation), LC06073 and MSM0021620828 (Czech Ministry of Education). AFGD also acknowledges financial support from grant LC06073 of the Czech Ministry of Education and of CzechGlobe Centre for Global Climate Change Impacts Studies, Reg. No. CZ.1.05/1.1.00/02.0073.

\section{REFERENCES}

Allawi TF (2006) Biological and ecological studies on Scymnus syriacus and Scymnus levaillanti (Coleoptera: Coccinellidae). Eur J Ent 103: 501-503.

Atlihan R, Chi H (2008) Temperature-dependent development and demography of Scymnus subvillosus (Coleoptera: Coccinellidae) reared on Hyalopterus pruni (Homoptera: Aphididae). J Econ Ent 101: 325-333.

Babu TR, Azam KM (1987) Biology of Cryptolaemus montrouzieri Mulsant (Coccinellidae: Coleoptera) in relation with temperature. Entomophaga 32: 381-386.

Bonner JT (1966) Size and Cycle: An Essay on the Structure of Biology. Princeton, NJ: Princeton University Press.

Brown HD (1972) On the biology of Lioadalia flavomaculata (Deg.) (Col., Coccinellidae), a predator of the wheat aphid (Scizoaphis graminum (Rond)) in South Africa. Bull Ent Res 61: 673-679.

Brown JH, Gillooly JF, Allen AP, Savage VM, West GB (2004) Toward a metabolic theory of ecology. Ecology 85: 1771-1789.

Butler GD (1982) Development time of Coccinella septempunctata in relation to constant temperatures (Col.: Coccinellidae). Entomophaga 27: 349-353.

Cheah CASJ, McClure MS (1998) Life history and development of Pseudoscymnus tsugae (Coleoptera: Coccinellidae), a new predator of the hemlock wooly adelgid (Homoptera: Adelgidae). Env Ent 27: 1531-1536.

Chong JH, Oetting RD, Osborne LS (2005) Development of Diomus austrinus Gordon (Coleoptera: Coccinellidae) on two mealybug prey species at five constant temperatures. Biol Control 33: 39-48.

Cohen AC, Brummett DL (1997) The non-abundant nutrient (NAN) concept as a determinant of predator - prey fitness. Entomophaga 42: 85-91.

Crawley MJ (1993) GLIM for Ecologists. Blackwell Science, Oxford. Cruz do Nascimento J, Mânica da Cruz IB, Monjeló LA, de Oliveìra AK (2002) Genetic components affecting embryonic development time of Drosophila melanogaster. Genet Mol Biol 25: 157-160.

Devlin RH, Biagi CA, Donaldson EM, Swanson P, Chan W-A (1994) Extraordinary salmon growth. Nature 371: 209-210. 
Devlin RH, Biagi CA, Yesaki TY, Smailus DE, Byatt JC (2001) Growth of domesticated transgenic fish. Nature 409: 781-782.

Dixon AFG, Hemptinne J-L, Kindlmann P (1997) Effectiveness of ladybirds as biological control agents: patterns and processes. Entomophaga 42: 71- 83.

Dixon AFG (1998) Aphid Ecology 2nd Ed. Chapman and Hall, London.

Grafton-Cardwell EE, Gu P, Montez GH (2005) Effects of temperature on development of vedalia beetle, Rodolia cardinalis (Mulsant). Biol Control 32: 473-478.

Hämäläinen M, Markkula M (1977) Cool storage of Coccinella septempunctata and Adalia bipunctata (Col.: Coccinellidae) eggs for use in the biological control in greenhouses. Ann Agr Fen 16: $132-136$.

Harvey PH, Pagel MD (1991) The comparative method in evolutionary biology. Oxford University Press, Oxford.

Hodek I (1958) Influence of temperature, relative humidity and photoperiodicity on the speed of development of Coccinella 7-punctata L. Čas Česk Spol Ent 55: 121-141.

Honěk A (1996) Geographical variation in thermal requirements for insect development. Eur J Ent 93: 303-312.

Honěk A, Kocourek F (1988) Thermal requirements for development of aphidophagous Coccinellidae (Coleopter), Chrysopidae, Hemerobidae (Neuroptera), and Syrphidae (Diptera): some general trends. Oecologia 76: 455-460.

Huang Z, Ren S, Musa PD (2008) Effects of temperature on development, survival, longevity, and fecundity of the Bemisia tabaci Gennadius (Homoptera: Aleyrodidae) predator, Axinoscymnus cardilobus (Coleoptera: Coccinellidae). Biol Control 46: 209-215.

Jarošik V, Honěk A, Dixon AFG (2002) Developmental Rate Isomorphy in Insects and Mites. Am Nat 160: 497-510.

Katsarou I, Margaritopoulos JT, Tsitsipis JA, Perdikis DC, Zarpas KD (2005) Effect of temperature on development, growth and feeding of Coccinella septempunctata and Hippodamia convergens reared on the tobacco aphid, Myzus persicae nicotianae. BioControl 50: 565-580.

Kontodimas DC, Eliopoulos PA, Stathas GJ, Economou LP (2004) Comparative temperature-dependent development of Nephus includens (Kirsch) and Nephus bisignatus (Boehman) (Coleoptera: Coccinellidae) preying on Planococcus citri (Risso) (Homoptera: Psudococcidae): evaluation of a linear and various nonlinear models using specific criteria. Env Ent 33: $1-11$.

Kreiter S, Iperti G (1984) Étude des potentialités biologiques et écologiques d'un prédateur aphidopage Olla V-nigrum Muls. (Coleoptera, Coccinellidae) en vue de son introduction en France. 109 Cong Nat Soc Savantes, Dijon 1984, 2: 275-282.

Kutuk H, Yigit (2007) Life table of Delphastus catalinae (Horn) (Coleoptera: Coccinellidae) on cotton whitefly, Bemisia tabaci (Genn.) (Homoptera: Aleyrodidae) as prey. J Plant Dis and Prot 114: $20-25$.

LaMana ML, Miller JC (1995) Temperature-dependent development in a polymorphic lady beetle, Calvia quatuordecimguttata (Coleoptera: Coccinellidae). Ann Ent Soc Am 88: 785-790.

LaMana ML, Miller JC (1998) Temperature-dependent development in an Oregon population of Harmonia axyridis (Coleoptera: Coccinellidae). Env Ent 27: 1001-1005.

Magro A, Lecompte E, Magne F, Hemptinne J-L, Crouau-Roy B (2010) Phylogeny of ladybirds (Coleoptera: Coccinellidae): Are the subfamilies monophyletic? Mol Phyl Evol 54: 833-848.

McMullen RD (1967) The effects of photoperiod, temperature and food supply on rate of development and diapause in Coccinella novemnotata, Can Ent 99: 578-586.
M'Hamed TB, Chemseddine M (2001) Assessment of temperature effects on the development and fecundity of Pullus mediterraneus (Col., Coccinellidae) and consumption of Saissetia oleae eggs (Hom., Coccoida). J Appl Ent 125: 527-531.

Michels GJ, Bateman AC (1986) Larval biology of two imported predators of the greenbug, Hippodamia variegata Goeze and Adalia flavomaculata DeGeer, under constant temperatures. Southwest Ent 11: 23-30.

Michels GJ, Behl RW (1991) A comparison of Coccinella septempunctata and Hippodamia convergens larval development on greenbugs at constant temperatures. Southwest Ent 16: $73-80$.

Miller JC (1992) Temperature-dependent development of the convergent lady beetle (Coleoptera:Coccinellidae). Env Ent 21: 197-201.

Miller JC, Paustian JW (1992) Temperature-dependent development of Eriopis connexa (Coleoptera: Coccinellidae). Env Ent 21: 1139-1142.

Mota JA, Soares AO, Garcia PV (2008) Temperature dependence for development of the whitefly predator Clitostethus arcuatus (Rossi). BioControl 53: 603-613.

Narnjo SE, Gibson RL, Walgenbach DD (1990) Development, survival, and reproduction of Scymnus frontalis (Coleoptera: Coccinellidae), an imported predator of Russian wheat aphid, at four fluctuating temperatures. Ann Ent Soc Am 83: 527-531.

Obrycki JJ, Tauber MJ (1981) Phenology of tree coccinellid species: thermal requirements for development. Ann Ent Soc Am 74: 31-36.

Obrycki JJ, Tauber MJ (1982) Thermal requirements for development of Hippodamia convergens (Coleoptera: Coccinellidae). Ann Ent Soc Am 75: 678-683.

Omkar, Pervez A (2004) Temperature-dependent development and immature survival of an aphidophagous ladybeetle, Propylea dissecta (Mulsant). J Appl Ent 128: 510-514.

Orr CJ, Obrycki JJ (1990) Thermal and dietary requirements for development of Hippodamia parenthesis (Coleoptera: Coccinellidae). Env Ent 19: 1523-1527.

Ponsonby DJ, Copland MJW (1996) Effect of temperature on development and immature survival in the scale insect predator, Chilocorus nigritus (F.) (Coleoptera: Coccinellidae). Biocontrol Sci Tech 6: 101-109.

Rana JS, Dixon AFG, Jarošík V (2002) Costs and benefits of prey specialization in a generalist insect predator. J Anim Ecol 71: $15-22$.

Ren SX, Stansly PA, Liu TX (2002) Life history of the whitefly predator Nephaspis oculatus (Coleoptera : Coccinellidae) at six constant temperatures. Biol Control 23:262-268.

Roy M, Brodeur J, Cloutier C (2002) Relationship between temperature and developmental rate of Stethorus punctillum (Coleoptera: Coccinellidae) and its prey Tetranychus mcdanieli (Acarina: Tetranychidae). Env Ent 31: 177-187.

Schanderl H, Ferran A, Larroque M. (1985) Les besoins trophiques et thermiques des larves de la coccinelle Harmonia axyridis $\mathrm{Pal}$ las. Agronomie 5: 417-421.

Schüder I, Hommes M, Larink O (2004) The influence of temperature on development of Adalia bipunctata (Coleoptera: Coccinellidae). Eur J Ent 101: 379-384.

Sibly RM, Brown JH (2007) Effects of body size and lifestyle on evolution of mammal life histories. Proc Nat Acad Sci 104: 17707-17712.

Srivastava S, Omkar (2003) Influence of temperature on certain biological attributes of a ladybeetle Coccinella septempunctata Linnaeus. Acta Ent Sinica 10: 185-193. 
Stathas GJ (2000) The effect of temperature on the development of the predator Rhyzobius lophanthae and its phenology in Greece. BioControl 45: 439-451.

Stathas GJ, Eliopoulos PA, Kontodimas DC, Siamos DT (2002) Adult morphology and life cycle under constant temperatures of the predator Rhyzobius lophanthae Blaisdell (Col., Coccinellidae). Anzeiger für Schädlingskunde 75: 105-109.

Stewart LA, Hemptinne J-L, Dixon AFG (1991) Reproductive tactics of ladybird beetles: relationships between egg size, ovariole number and developmental time. Funct Ecol 5: 380-385.
Uygun N, Atlihan (2000) The effect of temperature on development and fecundity of Scymnus levaillanti. BioControl 45: 453-462.

Wright EJ, Laing JE (1978) The effects of temperature on development, adult longevity and fecundity of Coleomegilla maculate lengi and its parasite, Perilitus coccinellae. Proc Ent Soc Ontario 109: 33-47.

Zhao DX, Wang ZW (1987) Influence of temperature on the development of the coccinellid beetle, Scymnus hoffmanni Weise. Acta Ent Sinica 30: 47-54. 